\title{
Penetration of Pacific zooplankton into the western Arctic Ocean tracked with molecular population genetics
}

\author{
R. J. Nelson ${ }^{1,2, *}$, E. C. Carmack ${ }^{1}$, F. A. McLaughlin ${ }^{1}$, G. A. Cooper ${ }^{2}$ \\ ${ }^{1}$ Fisheries and Oceans Canada - Institute of Ocean Sciences, 9860 West Saanich Road, Sidney, \\ British Columbia V8L 4B2, Canada \\ ${ }^{2}$ University of Victoria, Department of Biology, Centre for Biomedical Research, PO Box 3020, STN CSC, Victoria, \\ British Columbia V8W 3N5, Canada
}

\begin{abstract}
Calanus glacialis is an ecologically important marine copepod found throughout the Arctic Ocean with limited distributions in the North Pacific and North Atlantic Oceans. We employed molecular techniques to determine the population genetic structuring of C. glacialis across the boundaries of these 3 oceans. Examination of the DNA sequence of the 16S ribosomal RNA gene identified 2 predominant haplotypes which defined the Arctic and North Pacific (Bering Sea) populations. Advection from the Bering Sea into the Arctic as far as the western Canada Basin was detected, but C. glacialis from the Bering Sea was absent in the majority of Arctic Ocean samples. This indicates that $C$. glacialis from the Bering Sea was not reproductively established in the Arctic Ocean. Genetic divergence of Arctic and Bering Sea populations may have occurred during their isolation in the course of the Pleistocene glaciations, or, more recently, from unidirectional advection due to the northward current regime through the Bering Strait. Climate warming will increase opportunities for southern organisms to become established in the Arctic Ocean. The study of intraspecific genetic variation of C. glacialis has great potential in aiding the early detection of such ecological change.
\end{abstract}

KEY WORDS: Arctic Ocean · Zooplankton $\cdot$ Genetics $\cdot$ Bering Sea

Resale or republication not permitted without written consent of the publisher

\section{INTRODUCTION}

Flow through Bering Strait into the western Arctic Ocean is predominantly northward (Coachman et al. 1975). In the summer, this flow carries large quantities of phytoplankton (Springer \& McRoy 1993) and zooplankton (Springer et al. 1989), as well as nutrients (Coachman et al. 1975), into the Chukchi Sea. This biotic and geochemical influx fuels the highly productive ecosystem of the southern Chukchi Sea shelf (Grebmeier et al. 1988, Springer \& McRoy 1993).

The flow through Bering Strait is composed of 3 types of water (Coachman et al. 1975) (see Fig. 1). Anadyr Water, which flows along the western side of the strait, originates at the shelf break of the Bering Sea and is relatively cool and nutrient rich. Alaskan Coastal Water, which flows northward along the east- ern side of the strait, is strongly influenced by freshwater runoff, making it relatively fresh, warm and low in nutrients. Bering Shelf Water, which transits the strait between Anadyr and Alaskan Coastal waters, has characteristics intermediate to the latter 2 water types. Anadyr and Bering Shelf waters merge shortly after passing through Bering Strait and are collectively referred to as Bering Sea Water, whereas the Alaskan Coastal Water remains recognizable as it travels along the coast of Alaska in the Alaskan Coastal Current (Coachman et al. 1975).

Some quantity of Bering Sea Water travels northward in the Alaskan Coastal Current (Woodgate \& Aagaard 2005), while the bulk of this water fans out northward over the Chukchi Shelf (Windsor \& Chapman 2002) and is channelled according to bottom topography along 3 different exit routes from the 


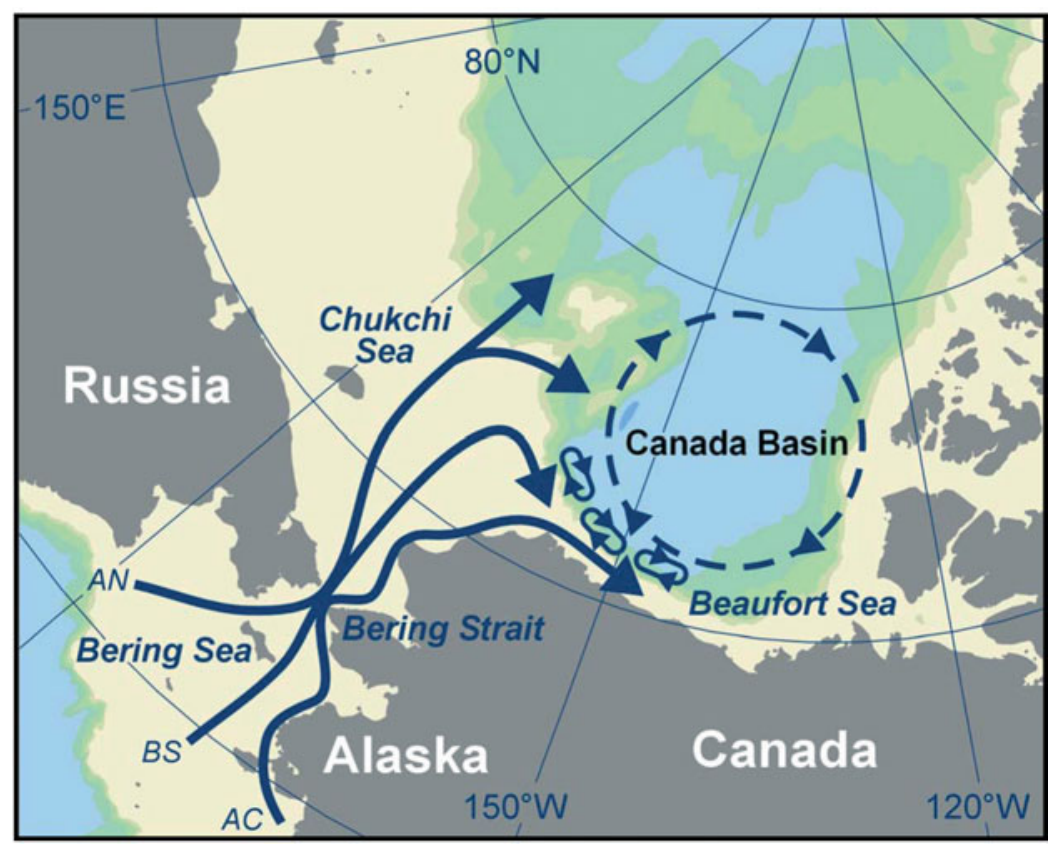

Fig. 1. Pathways of currents and oceanographic features of the northern Bering Sea and western Arctic Ocean. Heavy lines indicate general pathways taken by currents flowing from the Bering Sea into the western Arctic Ocean. Currents depicted are (from west to east): Anadyr (AN), Bering Shelf (BS), and Alaskan Coastal (AC). Also depicted is the Beaufort Gyre (dashed line) centered over the Canada Basin and the area of formation of eddies along the shelf break of the Chukchi and Beaufort Seas

Chukchi Sea (Weingartner et al. 2005, Woodgate et al. 2005). Two of these exit routes follow the shelf breaks of the Chukchi and Beaufort Seas eastward to the Canada Basin (Pickart et al. 2005). The coastally bound Alaskan Coastal Current also flows eastwards towards the Beaufort Sea (Mountain et al. 1976); both the Bering Sea and Alaskan Coastal waters have been detected along the shelf break of the Beaufort Sea, east of Point Barrow (Nikolopoulos \& Pickart in press). These pathways are all potential routes for penetration of southern flora and fauna into Arctic waters.

The biomass of zooplankton transported through Bering Strait peaks in mid-summer (Springer et al. 1989, Piatt \& Springer 2003). Each of the 3 types of water that pass through Bering Strait carries a different contingent of zooplankton northward into the Chukchi Sea. Oceanic copepods such as Neocalanus cristatus, Neocalanus plumcris, Metridia pacifica and Eucalanus bungii predominate in Anadyr water, and Acartia longerimis and Pseudocalanus spp. predominate in Alaskan coastal water (Springer et al. 1989). Calanus marshallae is reported to be the dominant copepod transported through Bering Strait (Springer et al. 1989) in Bering Shelf Water. C. marshallae (Frost 1974), E. bungii and N. cristatus (Hopcroft et al. 2005), as well as M. pacifica (Ashjian et al. 2003), have been observed in Arctic waters beyond the immediate environs of Bering Strait. Calanus glacialis is an ecologically important Arctic copepod that is also found on the Bering Sea shelf and along the western Pacific continental shelf as far south as the Sea of Okhotsk (Jaschnov 1970, Frost 1974). Transport of C. glacialis from the Bering Sea into the Arctic has not been documented to date because it is morphologically indistinguishable from C. glacialis of the Arctic.

Calanus glacialis is considered to be a shelf-associated copepod, with its greatest abundance and productivity in shelf break/slope waters at 50 to $1000 \mathrm{~m}$ in depth (Kosobokova \& Hirche 2001, Ashjian et al. 2003). The duration of the life cycle of C. glacialis has been observed to be either 1 yr (Grainger 1961, Safronov 1984, Smith et al. 1985) or 2 yr (Tande et al. 1985, see Conover 1988). Egg production begins in spring as animals ascend from depth to graze on ice algae and phytoplankton (Conover 1988, Hirche 1998). Observations suggest that water of at least $100 \mathrm{~m}$ depth may be required for overwintering (see Hirche 1991, Conover \& Sieferd 1993, Ashjian et al. 2003), and it is not known whether overwintering can occur successfully in water $<100 \mathrm{~m}$ deep.

In the present work we examined the genetic variation of populations of Calanus glacialis found in the Pacific, Arctic and Atlantic Oceans, in order to explore the ecological and evolutionary coupling between populations of the species found in different regions. Genetic divergence of C. glacialis in the Pacific and Arctic Oceans may have been promoted by the predominant 1-way flow through the Bering Strait, as well as by periodic closures of the Bering Strait during the Pleistocene. We therefore placed particular emphasis on the examination of populations found in the northern Bering Sea and western Arctic Ocean. With information regarding genetic heterogeneity of the species across the Pacific-Arctic boundary, we hope to be able to delimit the penetration of $C$. glacialis from the Pacific Ocean into Arctic waters. This would contribute to a better understanding of the ecological impact of expatriates in the Arctic. This approach may also prove to be a sensitive tool for monitoring for northward range expansion of Pacific C. glacialis associated with climate change. Here we have provided a genetic baseline, which could be used for such monitoring purposes. 


\section{MATERIALS AND METHODS}

Mixed zooplankton samples were collected by vertical net hauls with either a 335 or $236 \mu \mathrm{m}$ net (see Table 1, Fig. 2) and were preserved in $95 \%$ ethanol, as well as $10 \%$ buffered formalin, for most net hauls. The geographical range of Calanus glacialis partially overlaps the range of the morphologically similar congener C. marshallae on the Bering Sea Shelf and in the Bering Strait region (Frost 1974). In tows from these stations, we discriminated between these 2 species, first by working from the formalin-preserved samples and assessing the relative size of the accessory photoreceptor and prosome length according to Frost (1974), to determine whether $C$. marshallae was present. Presence and prosome size of $C$. marshallae were noted, and this information was used to pick C. glacialis individuals from the corresponding ethanol-preserved sample. In some of the samples we examined from the eastern Arctic, there is the potential that $C$. glacialis were found together with the congener $C$. finmarchicus; these 2 species were distinguished according to Fleminger \& Hulsemann (1977) and Hirche et al. (1994).

As an independent check of our taxonomic work on samples potentially containing Calanus marshallae and C. glacialis, we determined the DNA sequence of the 16S gene (see methods below) of 13 specimens of $C$. marshallae from a southerly sample in which we did not observe any C. glacialis. Out of these 13 individuals, 12 had a sequence identical to that published for C. marshallae (Bucklin et al. 1995). We observed this sequence in a total of 2 individuals, 1 each found in the samples BD7 and UTBS5; these samples were collected where it is likely that C. marshallae and C. glacialis cooccur. These individuals may have been misidentified individuals of C. marshallae and were removed from further analysis. This analysis indicates that overall our taxonomic work is accurate.

Table 1. Information for each sample site. Numbers for sampling sites refer to sites shown in Fig. 2. SWL: CCGS 'Sir Wilfrid Laurier'; SIV: 'Sedna IV'; MIR: RV 'Mirai'; LSL: CCGS 'Louis S. St. Laurent'; BS: Bering Shelf; SECS: southeastern Chukchi Sea; CB: Canada Basin; LS-BB: Labrador Sea-Baffin Bay; CAA: Canadian Arctic Archipelago; NCS: northern Chukchi Sea

\begin{tabular}{|c|c|c|c|c|c|c|c|c|c|c|}
\hline $\begin{array}{l}\text { Sampling } \\
\text { site }\end{array}$ & $\mathrm{N}$ & Stn & Region & Ship & $\begin{array}{c}\text { Date } \\
(\mathrm{m} / \mathrm{d} / \mathrm{yr})\end{array}$ & Lat. ${ }^{\circ} \mathrm{N}$ & Long. ${ }^{\circ} \mathrm{W}$ & $\begin{array}{l}\text { Plankton net } \\
\text { meshsize }(\mu \mathrm{m})\end{array}$ & $\begin{array}{l}\text { Tow depth } \\
\text { (m) }\end{array}$ & $\begin{array}{l}\text { Bottom depth } \\
(\mathrm{m})\end{array}$ \\
\hline 1 & 18 & SLIP1 & BS & SWL & $7 / 15 / 2002$ & 6200.67 & 17503.59 & 236 & 82 & 96 \\
\hline 2 & 21 & SLIP5 & BS & SWL & $7 / 15 / 2002$ & 6233.72 & 17333.33 & 236 & 50 & 69 \\
\hline 3 & 20 & BCS6 & BS & SWL & $7 / 16 / 2002$ & 6351.01 & 17223.54 & 236 & 40 & 45 \\
\hline 4 & 17 & UTBS5 & BS & SWL & $7 / 16 / 2002$ & 6440.03 & 16955.23 & 236 & 40 & 48 \\
\hline 5 & 13 & UTN1 & SECS & SWL & $7 / 17 / 2002$ & 6642.64 & 16823.92 & 236 & 30 & 34 \\
\hline 6 & 9 & BD6 & SECS & SWL & $7 / 18 / 2002$ & 6911.91 & 16608.74 & 236 & 26 & 31 \\
\hline 7 & 10 & CKS1 & SECS & SWL & $7 / 19 / 2002$ & 7037.02 & 16105.69 & 236 & 25 & 29 \\
\hline 8 & 9 & IT1 & SECS & SWL & $7 / 19 / 2002$ & 7041.17 & 16042.66 & 236 & 35 & 40 \\
\hline 9 & 5 & BD7 & SECS & SWL & $7 / 20 / 2002$ & 7109.69 & 15823.38 & 236 & 44 & 49 \\
\hline 10 & 6 & IT3 & CB & SWL & $7 / 22 / 2002$ & 7039.6 & 14954.00 & 236 & 15 & 17 \\
\hline 11 & 9 & IT5 & $\mathrm{CB}$ & SWL & $7 / 22 / 2002$ & 7006.93 & 14246.71 & 236 & 20 & 24 \\
\hline 12 & 15 & IT11 & CB & SWL & $7 / 27 / 2002$ & 7038.96 & 12742.62 & 236 & 100 & 115 \\
\hline 13 & 14 & IT27 & CAA & SWL & $8 / 10 / 2002$ & 6826.77 & 11125.46 & 236 & 100 & 120 \\
\hline 14 & 17 & S11 & LS-BB & SIV & $7 / 22 / 2002$ & 6107.00 & 6409.00 & 335 & 100 & 270 \\
\hline 15 & 11 & S20 & LS-BB & SIV & 8/8/2002 & 7046.00 & 6137.00 & 335 & 100 & 1625 \\
\hline 16 & 11 & S26 & CAA & SIV & $8 / 25 / 2002$ & 7330.00 & 9043.00 & 335 & 100 & 198 \\
\hline 17 & 10 & S29 & CAA & SIV & 9/2/2002 & 7054.00 & 9708.00 & 335 & 100 & 120 \\
\hline 18 & 19 & NW1 & CB & LSL & 8/9/2002 & 7559.10 & 15652.15 & 236 & 100 & 850 \\
\hline 19 & 19 & AL10 & $\mathrm{CB}$ & LSL & $8 / 20 / 2002$ & 7329.28 & 13659.60 & 236 & 100 & 3170 \\
\hline 20 & 14 & SB1 & CB & LSL & $8 / 23 / 2002$ & 7235.15 & 14059.78 & 236 & 100 & 3220 \\
\hline 21 & 14 & SB3 & CB & LSL & $8 / 25 / 2002$ & 7413.91 & 14822.35 & 236 & 100 & 3850 \\
\hline 22 & 10 & NW8 & CB & LSL & $8 / 27 / 2002$ & 7646.60 & 14857.49 & 236 & 100 & 3880 \\
\hline 23 & 14 & LS19 & CB & LSL & $8 / 20 / 2003$ & 7908.81 & 15954.37 & 236 & 100 & 3010 \\
\hline 24 & 22 & LS20 & $\mathrm{CB}$ & LSL & $8 / 21 / 2003$ & 8000.77 & 15000.33 & 236 & 100 & 3660 \\
\hline 25 & 11 & LS23 & $\mathrm{CB}$ & LSL & $8 / 23 / 2003$ & 780.33 & 14954.90 & 236 & 100 & 3823 \\
\hline 26 & 10 & LS26 & $\mathrm{CB}$ & LSL & $8 / 25 / 2003$ & 7700.79 & 14500.78 & 236 & 100 & 3757 \\
\hline 27 & 10 & LS27 & $\mathrm{CB}$ & LSL & $8 / 26 / 2003$ & 7659.23 & 14006.08 & 236 & 100 & 3675 \\
\hline 28 & 13 & HC11 & $\mathrm{CB}$ & MIR & $9 / 7 / 2004$ & 7429.65 & 15802.50 & 100 & 100 & 1500 \\
\hline 29 & 14 & HRC6 & NCS & MIR & $9 / 9 / 2004$ & 7500.00 & 17200.00 & 100 & 200 & 380 \\
\hline 30 & 11 & MRE4 & NCS & MIR & $9 / 11 / 2004$ & 7527.00 & 1784.80 & 100 & 331 & 1083 \\
\hline 31 & 13 & MRW3 & NCS & MIR & $9 / 12 / 2004$ & 7546.80 & 1794.20 & 100 & 300 & 1100 \\
\hline 32 & 13 & CAPE3 & NCS & MIR & $9 / 13 / 2004$ & 7539.00 & 17025.20 & 100 & 200 & 1250 \\
\hline 33 & 23 & CBN05 & $\mathrm{CB}$ & MIR & $9 / 21 / 2004$ & 7400.00 & 15200.00 & 100 & 300 & 3900 \\
\hline
\end{tabular}




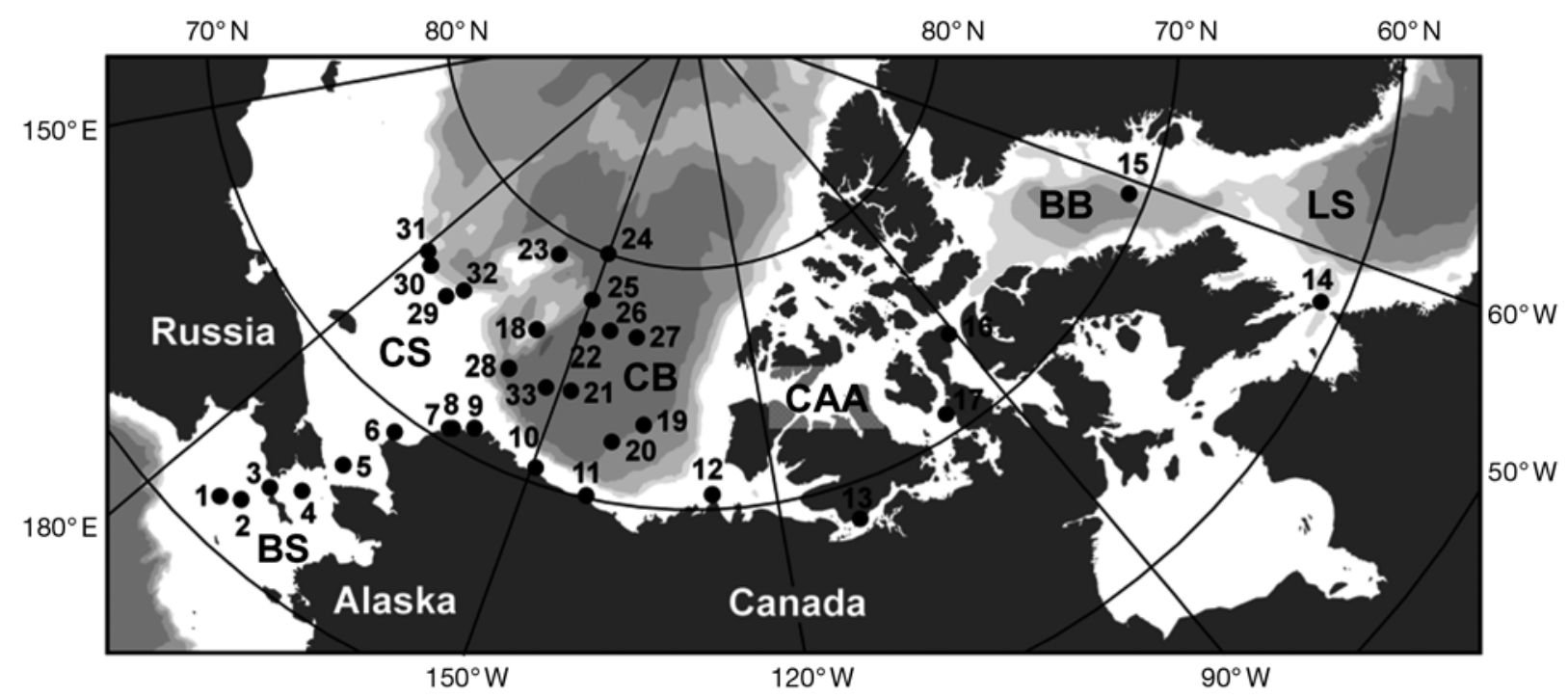

Fig. 2. Location of sampling sites. Dots indicate where samples were collected, and numbers adjacent to the dots refer to samples in Table 1. BS: Bering Sea; CS: Chukchi Sea; CB: Canada Basin; CAA: Canadian Arctic Archipelago; BB: Baffin Bay; LS: Labrador Sea

DNA was extracted by incubating individual zooplankters in $100 \mu \mathrm{l}$ of $10 \%$ Chelex-100 (Bio-Rad), $0.2 \%$ SDS and $0.4 \mathrm{mg}$ Proteinase $\mathrm{K} \mathrm{ml}^{-1}$ for $2 \mathrm{~h}$ at $55^{\circ} \mathrm{C}$, then at $95^{\circ} \mathrm{C}$ for $15 \mathrm{~min}$. A segment of the mitochondrial $16 \mathrm{~S}$ rRNA gene was amplified and sequenced with the primers 16sarRNA (5' CGCCTGTTTAACAAAAACAT 3') (Palumbi \& Benzie 1991) and 16sb2rRNA (5' ATT CAACATCGAGGTCACAAAC 3') (Lindeque et al. 2005). Sequencing was carried out with an Applied Biosystems 3700 sequencer. The computer program PHRED/PHRAP (Ewing \& Green 1998) was used for assembly of individual contigs from forward and reverse sequences, and CONSED (Gordon et al. 1998) was used to check the individual consensus sequences. Comparison and trimming of each individual consensus sequence was carried out with SEQMAN 5.05, DNAstar Inc.. The DNA sequences reported here are deposited in GenBank (Accession Numbers EU302866 -EU302988 and FJ628356-FJ628359).

For the genetic analysis, several different computer programs were utilized. DnaSP 4.10.09 (Rozas et al. 2003) was used to compute average number of nucleotide differences and format data for input into ARLEQUIN 3.11 (Excoffier et al. 2005). ARLEQUIN was also used to compute haplotype frequencies and diversities, conduct pairwise tests of genetic differentiation, as well as to perform analysis of molecular variance (AMOVA) (Excoffier et al. 1992). In the AMOVA, frequency differences and Jukes \& Cantor (1969) molecular distances between haplotypes were taken into consideration to calculate distribution of genetic variance within samples, between groups of samples, and within groups to test different hypotheses of genetic structure. For the
AMOVA, samples were grouped regionally as follows: Bering Sea Shelf (BS) Samples 1 to 4; southeastern Chukchi Sea (SS) Samples 5 to 9; northern Chukchi Sea (NCS) Samples 29 to 31; Canada Basin (CB) Samples 10 to 12, 18 to 28, 33); Canadian Arctic Archipelago (CAA) Samples 13, 16, 17; Labrador Sea-Baffin Bay (LS-BB) Samples 14 and15. In this analysis $F_{\mathrm{ST}}$ was taken to be analogous to Weir \& Cockerham's (1984) $\phi_{\mathrm{CT}}$ as reported by ARLEQUIN. Regional pairwise differentiation tests were performed with ARLEQUIN by pooling individual samples of each region as defined above. Pairwise $F_{\mathrm{ST}}$ among regions along with associated $\mathrm{p}$-values were also calculated. A $95 \%$ parsimony haplotype network, representing the relationship between haplotypes was constructed using the program TCS (Clement et al. 2000). Visualization of the geographical distribution of genetic variation was created by superimposing pie charts upon a map of the study region. To simplify this figure, low frequency haplotypes were pooled according to their relationship to Haplotype $\mathrm{H} 1$ or $\mathrm{H} 2$, as suggested by the parsimony network. Haplotypes were pooled and displayed as follows: $\mathrm{H} 2$ lineage $-\mathrm{H} 2, \mathrm{H} 6, \mathrm{H} 8, \mathrm{H} 13, \mathrm{H} 20$; H1 lineage - H1, H3, H4, H5, H9, H10, H11, H16, H18, H19, H21, H22, H23, H24, H25, H26. Haplotypes H7, H12, H14, H15 and H17 could not be unambiguously pooled into either lineage.

\section{RESULTS}

We determined the sequence of 271 base pairs of the 16S ribosomal RNA gene of 443 Calanus glacialis from the North Atlantic, Arctic and North Pacific Oceans. 
Table 2. Hierarchical $F_{\mathrm{ST}}$ analysis (AMOVA) of population structure. Region abbreviations are given in Table $1 . \mathrm{H}_{\mathrm{o}}$ : observed heterozygosity

\begin{tabular}{|c|c|c|c|c|c|}
\hline \multirow{2}{*}{ Structure } & \multirow{2}{*}{ No. of groups } & \multicolumn{3}{|c|}{ Variance component } & \multirow{2}{*}{$\begin{array}{c}F_{\mathrm{ST}} \\
\text { (probability of } H_{\mathrm{o}} \text { ) }\end{array}$} \\
\hline & & Within sites & $\begin{array}{l}\text { Among sites } \\
\text { (within group) }\end{array}$ & Among groups & \\
\hline \multicolumn{6}{|l|}{ Regional } \\
\hline $\mathrm{BS} \backslash \mathrm{NCS}+\mathrm{SECS} \backslash \mathrm{CB} \backslash \mathrm{CAA} \backslash \mathrm{LS}-\mathrm{BB}$ & 5 & 0.169 & 0.042 & 0.09 & $0.29(<0.01)$ \\
\hline Advection with Pacific water & & & & & \\
\hline $\mathrm{BS}+\mathrm{NCS}+\mathrm{SECS} \backslash \mathrm{CB} \backslash \mathrm{CAA} \backslash \mathrm{LS}-\mathrm{BB}$ & 4 & 0.169 & 0.05 & 0.08 & $0.27(<0.01)$ \\
\hline Advection Alaskan coast & & & & & \\
\hline $\mathrm{BS}+\mathrm{SECS} \backslash \mathrm{NCS} \backslash \mathrm{CB} \backslash \mathrm{CAA} \backslash \mathrm{LS}-\mathrm{BB}$ & 5 & 0.169 & 0.003 & 0.17 & $0.47(<0.01)$ \\
\hline
\end{tabular}

(Fig. 2, Table 1). In the entire sample set, we found 23 polymorphic sites defining 26 haplotypes (Table A1, available in MEPS Supplementary Material, www. int-res.com/articles/suppl/m381p129_app.pdf), with an average number of nucleotide differences of 0.55 . The majority of individuals carried 1 of 2 haplotypes, H1 found in 309 cases and $\mathrm{H} 2$ found in 95 cases; these haplotypes differed at 1 nucleotide site. The other 25 haplotypes were found at much lower frequencies, with 19 of them observed only once (Table A1). Within the samples, haplotype diversity ranged from 0.0 to 0.58 , with 9 samples having a haplotype diversity of 0.0 (Table A2, available at www.int-res.com/articles/suppl/ m381p129_app.pdf).

Haplotype frequencies were calculated for each sample (Table A2). Haplotype H1 was found in every sample, with frequencies ranging from 0.11 to 1.0 . Haplotype H2 was observed at a relatively high frequency (0.6 to 0.77) in samples collected in the northern Bering Sea and the southeastern Chukchi Sea (Samples 1 to 9; Fig. 2, Table A2). Haplotype H2 was observed at a lower frequency $(0.25$ to 0.05$)$ in 4 out of the additional 24 samples examined. These samples were clustered in the Canada Basin north of Point Barrow. The third most abundant haplotype, H14, was observed in a total of 9 cases across a broad area, including the Canada Basin, on the Beaufort shelf and in the northern Chukchi Sea region, but it was never observed in the Bering or southeastern Chukchi Seas.

With AMOVA it is possible to determine the correspondence of genetic variation with regional geographical groupings of samples. This allows for assessment of the extent of population distributions. To test the hypothesis of advection of Calanus glacialis into the Arctic from the Bering Sea, 3 AMOVAs were performed (Table 2). When samples were grouped regionally, an $F_{\mathrm{ST}}$ of 0.29 ( $\mathrm{p}<0.01)$ was calculated. To test for advection of $C$. glacialis from the Bering Sea into the Chukchi Sea, sam- ples from these regions were grouped; AMOVA in this instance produced an $F_{\mathrm{ST}}$ of $0.27(\mathrm{p}<0.01)$. As a further refinement of the advection hypothesis, the northern Chukchi Sea samples were removed from the BeringChukchi group for the third AMOVA; in this case, $F_{\mathrm{ST}}$ was 0.47 ( $p<0.01)$, the highest value seen, suggesting that this grouping most accurately reflected the genetic relationship between the samples.

To further explore the genetic relationship among different regions, individual samples were pooled within regions to carry out pairwise differentiation tests and calculate $F_{\mathrm{ST}}$ between them (Table 3 ). In the differentiation tests, the null hypothesis of genetic homogeneity could not be rejected between the Bering Sea and the southeastern Chukchi Sea, but every pairwise test was rejected between these 2 regions and all others. Similarly, the $F_{\mathrm{ST}}$ value between the Bering Sea and the southeastern Chukchi Sea was not significant, while between these regions and all others $F_{\mathrm{ST}}$ values were statistically significant. For both the Bering and southeastern Chukchi Seas, the lowest pairwise $F_{\mathrm{ST}}$ value detected was with the Canada Basin. These results confirm that samples of Calanus glacialis from the Bering and southeastern Chukchi Seas are likely drawn from the same population, as suggested by AMOVA, and that there is reproductive isolation between C. glacialis from the Pacific and Arctic Oceans.

The hypothesis of a unique population of Calanus glacialis being advected into the Arctic through Bering

Table 3. Pairwise differentiation test and pairwise $F_{\mathrm{ST}}$ between regionally pooled samples. Pairwise differentiation test is shown above the diagonal, while pairwise $F_{\mathrm{ST}}$ is shown below the diagonal. Region abbreviations, see Table 1

\begin{tabular}{|ccccccc|}
\hline & BS & SECS & NCS & CB & CAA & LS-BB \\
\hline BS & - & 0.76 & $<0.001$ & $<0.001$ & $<0.001$ & $<0.001$ \\
SECS & 0.00 & - & $<0.001$ & $<0.001$ & $<0.001$ & $<0.001$ \\
NCS & $0.60(<0.01)$ & $0.68(<0.01)$ & - & 0.97 & 0.34 & 0.35 \\
CB & $0.50(<0.01)$ & $0.54(<0.01)$ & $0.03(0.01)$ & - & 0.87 & 0.76 \\
CAA & $0.60(<0.01)$ & $0.68(<0.01)$ & 0.00 & $0.037(0.03)$ & - & 0.56 \\
LS-BB & $0.54(<0.01)$ & $0.60(<0.01)$ & 0.00 & $0.01(0.16)$ & 0.00 & - \\
& & & & & & \\
\hline
\end{tabular}


Strait can be explored by considering the prevailing hydrographic conditions where the samples were collected, keeping in mind the reported swimming speed of $0.74 \mathrm{~cm} \mathrm{~s}^{-1}$ for a copepod of comparable size to $C$. glacialis (Enright 1977). Samples 1 and 2 were collected in water $<100 \mathrm{~m}$ deep (Figs. 1 \& 2), where the northward flow has been reported to be as high as $10 \mathrm{~cm} \mathrm{~s}^{-1}$ (Schumacher et al. 1983, Clement et al. 2005). These samples had Haplotype $\mathrm{H} 2$ frequencies of 0.61 and 0.62 , respectively. Sample 3, collected in $45 \mathrm{~m}$ of water in the Anadyr Strait, where flows of up to $40 \mathrm{~cm} \mathrm{~s}^{-1}$ have been reported (Coachman 1993), had a Haplotype H2 frequency of 0.75 . Sample 4 , which was collected in water $48 \mathrm{~m}$ deep with a typical northward current of 20 to $30 \mathrm{~cm} \mathrm{~s}^{-1}$ (Coachman 1993), had a Haplotype $\mathrm{H} 2$ frequency of 0.77 .

North of Bering Strait, Sample 5 was collected in $34 \mathrm{~m}$ of water and had a Haplotype $\mathrm{H} 2$ frequency of 0.77. This region is dominated by Pacific water (Fig. 1), with northward flows that are $20 \mathrm{~cm} \mathrm{~s}^{-1}$ on average (Coachman et al. 1975). Samples 6 to 9 were collected in water $<50 \mathrm{~m}$ deep, north of Bering Strait, along the coast of Alaska, where Pacific water is known to flow at speeds of approximately $15 \mathrm{~cm} \mathrm{~s}^{-1}$ (Fig. 1) (Mountain et al. 1976, Aagaard 1984). These samples had Haplotype $\mathrm{H} 2$ frequencies of $0.67,0.70$ and 0.78 and 0.6 , respectively. In summary, the distribution of Haplotype H2 interpreted along with prevailing hydrographic conditions indicates that south to north advection underlies the pattern observed.

Four additional samples contained Haplotype H2. These 4 samples $(18,22,28$ and 33) are found in the Canada Basin, where newly arrived Pacific water has been observed (Manley \& Hunkins 1985, Pickart et al. 2005, Sumata \& Shimada 2007).

Samples 29 through 32 were collected in the northern Chukchi Sea. Haplotype H2 was not observed in these samples. The null hypothesis of genetic homogeneity could not be rejected between Calanus glacialis from this region when tested against the Canada Basin, Canadian Arctic Archipelago and Baffin BayLabrador Sea regions (Table 3 ), but the pairwise $F_{\mathrm{ST}}$ value indicated some genetic distinction between the northern Chukchi Sea and Canada Basin.

Out of 63 individuals collected in the Canadian Arctic Archipelago, Baffin Bay and Labrador Sea, 61 were Haplotype $\mathrm{H} 1$ and 2 had unique haplotypes. In regional analyses (Table 3), the null hypothesis of genetic homogeneity could not be rejected between the Canada Basin and either the Canadian Arctic Archipelago or Baffin Bay-Labrador Sea regions. However, the $F_{\mathrm{ST}}$ value calculated between the Canada Basin and the Canadian Arctic Archipelago was statistically significant. When the low frequency haplotypes were pooled as a class and pairwise differentiation tests were conducted, the hypothesis of genetic homogeneity was rejected between the Canada Basin and the Canadian Arctic Archipelago ( $p=0.038)$, but it was not rejected between the Canada Basin and Baffin BayLabrador Sea regions $(p=0.41)$.

A 95\% parsimony haplotype network representing the relationship between haplotypes suggested the existence of 2 lineages, one typified by Haplotype H1 and the other by Haplotype H2 (Fig. 3). One haplotype (H15) could not be placed into the parsimony network. Visual inspection of the geographical distribution of these lineages, displayed by pie charts superimposed on the study region, showed widespread distribution of the $\mathrm{H} 1$ lineage, and a concentration of the H2 lineage in the northern Bering and southeastern Chukchi Seas, with a low frequency distribution in the Canada Basin north of Point Barrow (Fig. 4).

\section{DISCUSSION}

The relatively high frequency of Haplotype H2 south of Bering Strait indicates that Calanus glacialis in the Bering Sea and Arctic Ocean are genetically distinct. Because the currents in the northern Bering Sea and Bering Strait are primarily northward (Schumacher et al. 1983, Clement et al. 2005) and exceed the speed at which C. glacialis can swim (Enright 1977), it is likely that the animals we collected in the southeastern Chukchi Sea were advected from the northern Bering Sea through Bering Strait. The AMOVA, pairwise dif-

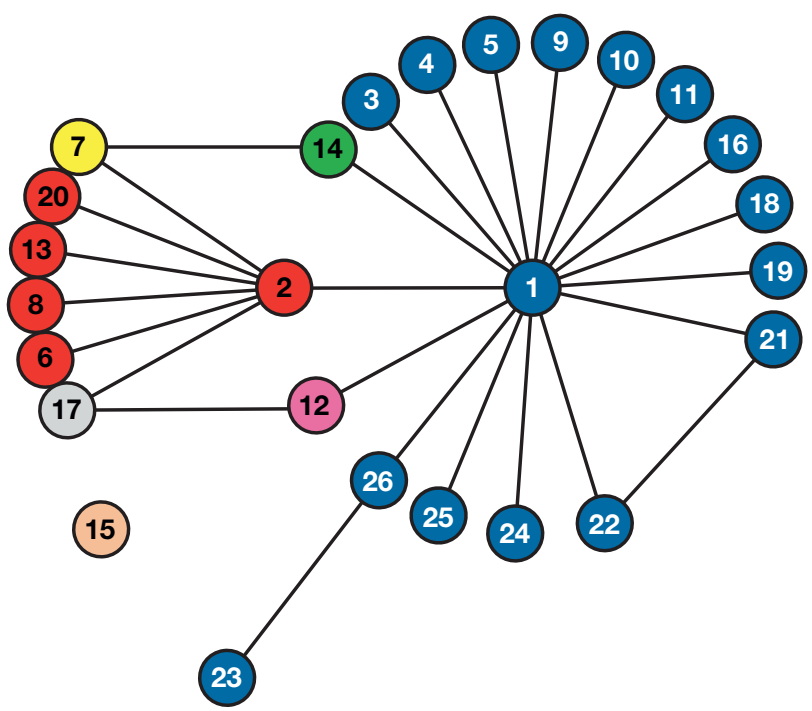

Fig. 3. Parsimony network. Each circle represents a unique haplotype. Numbers within each circle refer to Table A1 (Supplementary Material, available at www.int-res.com/articles/ suppl/m381p129_app.pdf). Colours indicate the manner in which each of the haplotypes was pooled for display in Fig. 4 


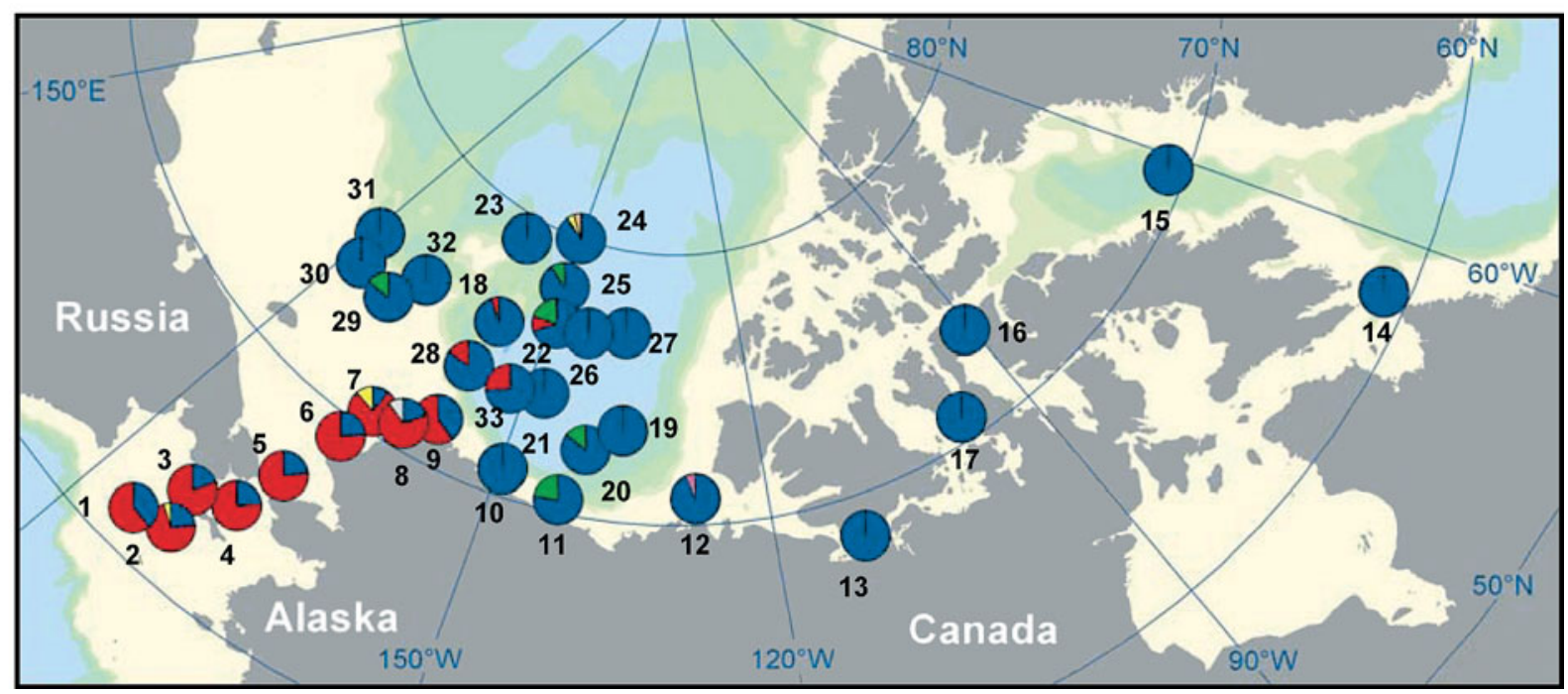

Fig. 4. Geographical distribution of lineages. Pie charts placed at the location where the samples were collected show the frequency of the $\mathrm{H} 1$ lineage (blue) and of the H2 lineage (red). Haplotypes that could not be placed unambiguously into either of the H1 or H2 lineages are shown in colours as depicted in Fig. 3. Numerals adjacent to pie charts refer to sample numbers in Table 1

ferentiation tests and the analysis of $F_{\mathrm{ST}}$ indicate that samples of C. glacialis from the northern Bering Sea and from the southeastern Chukchi Sea are drawn from the same population. The presence of both the H1 and H2 lineages in the northern Bering and southeastern Chukchi Seas may be due to mixing of the Arctic and Pacific populations due to occasional wind-driven southward flow through Bering Strait (Coachman \& Aagaard 1988, Roach et al. 1995, Weingartner et al. 1999). Alternatively, the $\mathrm{H} 1$ and $\mathrm{H} 2$ lineages may coexist in the Pacific Ocean. A similar phylogenetic break between Pacific and Arctic populations of the planktonic protist Neogloboquadrina pachyderma was detected by Darling et al. (2007), although these authors found no representation of the Pacific type in Arctic waters.

Haplotype $\mathrm{H} 2$ was found at low frequencies in 4 samples collected north of Point Barrow in the Canada Basin; this represents the deepest penetration of Bering Sea Calanus glacialis into the Arctic that we detected. Copepods were likely transported with Pacific water to this location in wind-driven flows, such as proposed by Sumata \& Shimada (2007), or via shelf-break eddies entrained in the Beaufort Gyre (Manley \& Hunkins 1985, D'Asaro 1988, Pickart et al. 2005, Spall et al. 2008) (see Fig. 1). Llinas et al. (2009) found Pacific zooplankton in a cold-core eddy in the same general area where we observed Haplotype $\mathrm{H} 2$ in the Canada Basin; this is consistent with our observations and indicates eddy-mediated transport. It is likely that both of these mechanisms play a role in transporting Pacific zooplankton into the Canada Basin depending on local currents, winds and ice cover.
The transport time from Bering Strait to Pt. Barrow in the Alaskan Coastal current is estimated to be approximately $4 \mathrm{mo}$, based on a current velocity of $10 \mathrm{~cm} \mathrm{~s}^{-1}$ (Mountain et al. 1976, Aagaard 1984, Woodgate et al. 2005). Transport time for copepods to be carried from Bering Strait to the furthest of the stations where we detected Haplotype $\mathrm{H} 2$ in the Canada Basin could range from 8 mo to $>1$ yr. In laboratory experiments, Calanus glacialis survived 9 mo under starvation conditions (Hirche \& Bohrer 1987). Although it is difficult to compare laboratory conditions to those found in nature, it is not unreasonable to assume that $C$. glacialis from the northern Bering Sea may be able to survive for 8 mo or more (perhaps with some feeding) and be transported into the Canada Basin.

The presence of Haplotype H2 along pathways of Pacific water in the Arctic and the lack of Haplotype H2 in the majority of the Arctic samples indicates that Bering Sea Calanus glacialis is not reproductively established in the Arctic. Plourde et al. (2005) found that, generally, reproduction was strong among Calanus glacialis/marshallae (they did not separate these 2 species in their study) associated with Pacific water in the Arctic. Presumably then, C. glacialis that is advected through Bering Strait with Pacific water has the potential to encounter conditions conducive to survival of the species, yet Haplotype $\mathrm{H} 2$ was not observed in the majority of the C. glacialis specimens from the Arctic that we genotyped.

The Chukchi shelf may be a partial barrier to the passage of Calanus glacialis from the Bering Sea into the Arctic. The specific overwintering requirements of the species are not known, but observations suggest 
that water of at least $100 \mathrm{~m}$ depth may be required (see Hirche 1991, Conover \& Sieferd 1993, Ashjian et al. 2003). If this is the case, the Chukchi shelf, which is $<100$ m deep, does not provide suitable overwintering habitat. High winter mortality here would inhibit the establishment of Bering Sea C. glacialis in the Arctic simply by reducing the number of invading animals. In a similar manner, high winter mortality on the shallow Bering Sea Shelf may promote reproductive isolation of Arctic and Pacific populations if animals most successfully overwinter and reproduce in the deeper water of the southern Bering Sea. Seasonal ice cover makes it difficult to collect information regarding the overwintering habitat of C. glacialis; however, it is clear this knowledge is of vital importance to understanding the ecology and evolution of this species in the northern Pacific and western Arctic Oceans.

The connection between the Pacific and Arctic Oceans is thought to have opened approximately 5.32 million years ago (Gladenkov et al. 2002), making the Arctic Ocean a transit route for biotic exchange between the Atlantic and Pacific Oceans (Vermeij 1991, Lindstrom 2001, Nikula et al. 2007, Reid et al. 2007). Since this connection was first established, it has been disrupted multiple times due to the rise and fall of the sea level during the glaciations of the Pleistocene epoch (1.8 million to 11.8 thousand years ago). This promoted independent evolutionary trajectories of Atlantic and Pacific taxa, leading to their vicariant speciation (Grant \& Stahl 1988, Collins et al. 1996).

The glacial events of the Pleistocene may have restricted gene flow between Calanus glacialis in the Pacific and Arctic Oceans, leading to the genetic divergence we observe here. One-way migration due to the predominant northward flow through Bering Strait may have also promoted genetic divergence in the past and may continue to do so. By whatever mechanism it is caused, isolation may have allowed for adaptation of Pacific populations to their local conditions, resulting in low fitness of southern animals in Arctic waters. This may be contributing to the failure of C. glacialis from the Bering Sea to become established in Arctic waters.

We did not observe Haplotype $\mathrm{H} 2$ among the Calanus glacialis sampled at 4 sites in the northern Chukchi Sea, where Bering Sea Water is detectable (Weingartner et al. 2005). Assuming a speed of $5 \mathrm{~cm} \mathrm{~s}^{-1}$ across the Chukchi Shelf (Woodgate et al. 2005), transport to this area from Bering Strait is estimated at approximately 8 mo. Maladaptation to Arctic conditions or high winter mortality on the shelf may have prevented C. glacialis from the Bering Sea to travel to this location in numbers sufficient to be detected by our sampling.

Every Bering Sea Calanus glacialis is advected through Bering Strait, ensuring its continuing presence in Arctic waters, but these animals appear to play only a transient ecological role. Advected copepods are likely to be most viable when first entering into the Arctic. As they penetrate further into Arctic waters, their viability may decline due to differences between their native and new habitats. Because of this, they will play an increasingly passive ecological role, to be consumed or die, rather than grazing, excreting and reproducing. Thus, the food-web and carbon-cycling impacts of expatriates will change as they are transported further into a habitat for which they are not adapted. This effect may contribute to the mismatch between primary production and grazing zooplankton in the southern Chukchi Sea region (Springer \& McRoy 1993), which results in a large quantity of carbon export to the benthos due to the sinking of unconsumed phytoplankton biomass (Grebmeier et al. 2006a).

The 16S mitochondrial RNA gene is not typically used for examination of intraspecific population differentiation, because it generally does not show a large amount of genetic variability within a species. Although we observed only low levels of genetic variation in this study, the geographical distribution of the variation we detected is clearly non-random and supports the interpretation of genetic divergence between Calanus glacialis of the Pacific and Arctic Oceans. Because of the low levels of genetic variation we detected, our ability to test for finer scale population divergence is limited. For instance, our results regarding genetic differentiation between the Canada Basin and the northern Chukchi Sea and regions to the east are somewhat equivocal. A more variable genetic marker should be used to explore questions of finer scale population genetic structure. Our observation of a unique population of C. glacialis in the Bering Sea raises questions concerning the evolutionary history of this population with regard to that of C. glacialis of the Arctic and that of the congener C. marshallae. Again, the low overall variation detected here limits our conclusions in this regard. However, this topic is of vital interest, and we are currently increasing our genomic coverage to more exhaustively explore this evolutionary relationship.

There is increasing evidence of change in both the physical environment and the ecology of the Arctic (Symon et al. 2005). The most dramatic of these changes is the reduction in the extent, duration and thickness of Arctic sea ice over the last few decades (Serreze et al. 2007). This will generally lead to oceanic conditions resembling those found further south, which will likely foster the establishment of Bering Sea Calanus glacialis and other Pacific endemics in the Arctic Ocean. A northward shift in benthic community structure has been observed in the Being Sea (Greb- 
meier et al. 2006b), which may foreshadow a similar shift in pelagic organisms in the Chukchi Sea. The adaptive divergence between $C$. glacialis from the Bering Sea and the Arctic Ocean may not be as great as that between Pacific and Arctic endemic species. Because of this, a relatively small alteration in oceanic conditions in the Arctic could result in a northward range expansion of C. glacialis from the Bering Sea. The genetic results we have presented here provide a baseline and a survey method for monitoring the stability of the Arctic-Pacific pelagic ecosystem boundary.

Acknowledgements. For sample collection we thank J. Lemire, I. Deslandes, S. Toews, C. Coray, S. Chiba, and the officers and crew of 'Sedna IV', Canadian Coast Guard ships 'Sir Wilfrid Laurier' and 'Louis S. St. Laurent', and the Japan Agency for Marine-Earth Science and Technology research vessel 'Mirai'. We thank B. Frost for useful discussions, and M. Galbriath for taxonomic work. B. Jayme collected samples and carried out DNA sequencing. This work was funded by a National Sciences and Engineering Research Council of Canada grant to R.J.N. and Fisheries and Oceans Canada.

\section{LITERATURE CITED}

Aagaard K (1984) The Beaufort undercurrent. In: Barnes P, Reimnitz E (eds) The Alaskan Beaufort Sea: ecosystems and environment. Academic Press, New York, p 47-71

Ashjian CJ, Campbell RG, Welch HE, Butler M, VanKeuren D (2003) Annual cycle in abundance, distribution, and size in relation to hydrography of important copepod species in the western Arctic Ocean. Deep-Sea Res I 50:1235-1261

Bucklin AC, Frost BW, Kocher TD (1995) Molecular systematics of six Calanus and three Metridia species (Calanoida: Copepoda). Mar Biol 121:655-664

> Clement M, Posada D, Crandall K (2000) TCS: a computer program to estimate gene genealogies. Mol Ecol 9: $1657-1660$

Clement JL, Maslowski W, Cooper LW, Grebmeier JM, Walczowski W (2005) Ocean circulation and exchanges through the northern Bering Sea: 1979-2001 model results. Deep-Sea Res II 52:3509-3540

> Coachman LK (1993) On the flow field in the Chirikov Basin. Cont Shelf Res 13:481-488

Coachman LK, Aagaard K (1988) Transport through Bering Strait: annual and interannual variability. J Geophys Res 93:535-539

Coachman LK, Aagaard K, Tripp RB (1975) Bering Strait. The regional and physical oceanography. University of Washington Press, Seattle, WA

Collins TM, Frazer K, Palmer AR, Vermeij GJ, Brown W (1996) Evolutionary history of northern hemisphere Nucella (Gastropoda, Muricidae): molecular, morphological, ecological, and paleontological. Evolution 50:2287-2304

Conover RJ (1988) Comparative life histories in the genera Calanus and Neocalanus in high latitudes of the northern hemisphere. Hydrobiologia 167/168:127-142

Conover RJ, Sieferd TD (1993) Dark-season survival strategies of coastal zone zooplankton in the Canadian Arctic. Arctic 46:303-311

$>$ D'Asaro EA (1988) Observations of small eddies in the Beaufort Sea. J Geophys Res 93:6669-6684
Darling KF, Kucera M, Wade C (2007) Global molecular phylogeography reveals persistent Arctic circumpolar isolation in a marine planktonic protist. Proc Natl Acad Sci USA 104:5002-5007

Enright JT (1977) Copepods in a hurry: sustained high-speed upward migration. Limnol Oceanogr 22:118-125

Ewing B, Green P (1998) Base calling of automated sequencer traces using phred. II. Error probabilities. Genome Res 8: 186-194

Excoffier L, Smouse P, Quattro J (1992) Analysis of molecular variance inferred from metric distances among DNA haplotypes: application to human mitochondrial DNA restriction data. Genetics 131:479-491

Excoffier L, Laval G, Schneider S (2005) Arlequin Ver. 3.0: an integrated software package for population genetics data analysis. Evol Bioinform Online 1:47-50

Fleminger A, Hulsemann K (1977) Geographical range and taxonomic divergence in North Atlantic Calanus (C. helgolandicus, C. finmarchicus and C. glacialis). Mar Biol 40:233-248

Frost BW (1974) Calanus marshallae, a new species of calanoid copepod closely allied to the sibling species $C$. finmarchicus and C. glacialis. Mar Biol 26:77-99

Gladenkov AY, Oleinik AE, Marincovich L Jr, Barinov KB (2002) A refined age for the earliest opening of Bering Strait. Palaeogeogr Palaeoclimatol Palaeoecol 183: 321-328

Gordon D, Abajian C, Green P (1998) Consed: a graphical tool for sequence finishing. Genome Res 8:195-202

Grainger EH (1961) The copepods Calanus glacialis (Jaschnov) and CaIanus finmarchicus (Gunnerus) in Canadian Arctic-Sub-arctic waters. J Fish Res Board Can 18: 663-678

Grant WS, Stahl G (1988) Evolution of Atlantic and Pacific cod: loss of genetic variability and gene expression in Pacific cod. Evolution 42:138-146

Grebmeier JM, McRoy CP, Feder HM (1988) Pelagic-benthic coupling on the shelf of the northern Bering and Chukchi Seas. 1. Food supply source and benthic biomass. Mar Ecol Prog Ser 48:57-67

Grebmeier JM, Cooper LW, Feder HM, Sirenko BI (2006a) Ecosystem dynamics of the Pacific-influenced northern Bering and Chukchi Seas in the Amerasian Arctic. Prog Oceanogr 71:331-361

Grebmeier JM, Overland JE, Moore SE, Farley EV and others (2006b) A major ecosystem shift in the northern Bering Sea. Science 311:1461-1464

> Hirche HJ (1991) Distribution of dominant calanoid copepod species in the Greenland Sea during late fall. Polar Biol 11: 351-362

Hirche HJ (1998) Dormancy in three Calanus species (C. finmarchicus, C. glacialis and C. hyperboreus) from the North Atlantic. Arch Hydrobiol 52(Spec Issue):359-369

Hirche HJ, Bohrer RN (1987) Reproduction of the Arctic copepod Calanus glacialis in Fram Strait. Mar Biol 94:11-17

Hirche HJ, Hagen W, Mumm N, Richter C (1994) The Northeast Water Polynya, Greenland Sea. III. Meso- and macrozooplankton distribution and production of dominant herbivorous copepods during spring. Polar Biol 14: $491-503$

> Hopcroft RR, Clarke C, Nelson RJ, Raskoff KA (2005) Zooplankton communities of the Arctic's Canada Basin: the contribution by smaller taxa. Polar Biol 28:198-206

> Jaschnov WA (1970) Distribution of Calanus species in the seas of the Northern Hemisphere. Int Rev Gesamten Hydrobiol 55:197-212

Jukes T, Cantor C (1969) Evolution of protein molecules. In: 
Munro HN (ed) Mammalian protein metabolism. Academic Press, New York, p 21-132

Kosobokova KN, Hirche HJ (2001) Reproduction of Calanus glacialis in the Laptev Sea, Arctic Ocean. Polar Biol 24: $33-43$

Lindeque PK, Hay SJ, Heath MR, Ingvarsdottir A, Rasmussen J, Smerdon GR, Waniek JJ (2005) Integrating conventional microscopy and molecular analysis to analyse the abundance and distribution of four Calanus congeners in the North Atlantic. J Plankton Res 28:221-238

Lindstrom SC (2001) The Bering Strait connection: dispersal and speciation in boreal macroalgae. J Biogeogr 28: 243-251

Llinas L, Pickart RS, Mathis JT, Smith SL (2009) Zooplankton inside an Arctic Ocean cold-core eddy: probable origin and fate. Deep-Sea Res II (in press)

Manley TO, Hunkins K (1985) Mesoscale eddies of the Arctic Ocean. J Geophys Res 90:4911-4930

Mountain DG, Coachman LK, Aagaard K (1976) On the flow through Barrow Canyon. J Phys Oceanogr 6:461-470

Nikolopoulos A, Pickart RS (2009) The western Arctic boundary current at $152 \mathrm{~W}$ : structure, variability and transport. Deep-Sea Res II (in press)

Nikula R, Strelkov P, Vainola R (2007) Diversity and transArctic invasion history of mitochondrial lineages in the North Atlantic Macoma balthica complex (Bivalva: Tellinidae). Evolution 61:928-941

Palumbi SR, Benzie J (1991) Large mitochondrial DNA differences between morphologically similar penaeid shrimp. Mol Mar Biol Biotechnol 1:27-34

Piatt J, Springer AM (2003) Advection, pelagic food webs and the biogeography of seabirds in Berengia. Mar Ornithol 31:141-154

Pickart RS, Weingartner TJ, Zimmermann S, Torres DJ, Pratt LJ (2005) Flow of winter-transformed Pacific water into the western Arctic. Deep-Sea Res II 52:3175-3198

Plourde S, Campbell RG, Ashjian CJ, Stockwell D (2005) Seasonal and regional patterns in egg production of Calanus glacialis/marshallae in the Chukchi and Beaufort Seas during spring and summer, 2002. Deep-Sea Res II 52:3411-3426

Reid PC, Johns DG, Edwards M, Starr M, Poulin M, Pauli S (2007) A biological consequence of reducing Arctic ice cover: arrival of the Pacific diatom Neodenticula seminae in the North Atlantic for the first time in 800000 years. Glob Change Biol 13:1910-1921

Roach AT, Aagaard K, Pease CH, Salo SA, Weingartner T, Pavlov V, Kulakov M (1995) Direct measurements of transport and water properties through the Bering Strait. J Geophys Res 100:443-457

Rozas J, Sanchez-Delbarrio JC, Messeguer X, Rozas R (2003) DnaSP, DNA polymorphism analyses by the coalescent and other methods. Bioinformatics 19:2496-2497

Editorial responsibility: Jon Hare,

Narragansett, Rhode Island, USA
Safronov SG (1984) Ecology of the copepod Calanus glacialis from the Sea of Okhotsk. Sov J Mar Biol 10:200-203

Schumacher JD, Aagaard K, Pease CH, Tripp RB (1983) Effects of a shelf polynya on flow and water properties in the northern Bering Sea. J Geophys Res 88:2723-2732

Serreze MC, Holland MM, Stroeve J (2007) Perespectives on the Arctic's shrinking ice cover. Science 315:1535-1536

Smith SL, Smith WO, Codispoti LA, Wilson DL (1985) Biological observations in the marginal ice zone of the East Greenland Sea. J Mar Res 43:693-717

Spall MA, Pickart RS, Fratantoni PS, Plueddemann AJ (2008) Western Arctic shelfbreak eddies. Formation and transport. J Phys Oceanogr 38:1644-1668

Springer AM, McRoy CP (1993) The paradox of pelagic food webs in the northern Bering Sea. III. Patterns of primary production. Cont Shelf Res 13:575-599

Springer AM, McRoy CP, Turko KR (1989) The paradox of pelagic food webs in the northern Bering Sea. II. Zooplankton communities. Cont Shelf Res 9:359-386

> Sumata H, Shimada K (2007) Northward transport of Pacific summer water along the Northwind Ridge in the western Arctic Ocean. J Oceanogr 63:363-378

Symon C, Arris L, Heal B (eds) (2005) Arctic climate change impact assessment. Cambridge University Press, New York

Tande KS, Hassel A, Slagstad D (1985) Gonad maturation and possible life history strategies in Calanus finmarchicus and Calanus glacialis in the northwestern part of the Barents Sea. In: Gray JS, Christiansen ME (eds) Marine biology of polar regions and effects of stress on marine organisms. J Wiley \& Sons, New York, p 141-155

Vermeij G (1991) Anatomy of an invasion: the trans-Arctic interchange. Paleobiology 17:281-307

Weingartner TJ, Danielson S, Sasaki Y, Pavlov VK, Kulakov M (1999) The Siberian coastal current: a wind- and buoyancy-forced Arctic coastal current. J Geophys Res 104: $697-713$

Weingartner TJ, Aagaard K, Woodgate RA, Danielson S, Sasaki Y, Cavalieri D (2005) Circulation on the north central Chukchi Sea shelf. Deep-Sea Res II 52:3150-3174

Weir BS, Cockerham CC (1984) Estimating F-statistics for the analysis of population structure. Evolution 38:1358-1370

Windsor P, Chapman DC (2002) Pathways of Pacific water across the Chukchi Sea: a numerical model study. J Geophys Res 109:C03002. doi:1029/2003JC001962

Woodgate RA, Aagaard K (2005) Revising the Bering Strait freshwater flux into the Arctic Ocean. Geophys Res Lett 32:L02602. doi:10.1029/2004GL0211747

Woodgate RA, Aagaard K, Weingartner TJ (2005) Monthly temperature, salinity, and transport variability of the Bering Strait through flow. Geophys Res Lett 32:L04601. doi:10.1029/2004GL021880

Submitted: January 5, 2008; Accepted: January 21, 2009

Proofs received from author(s): April 1, 2009 